\title{
THE EFFECT OF BRAND TRUST AND BRAND COMMUNITY COMMITMENT ON ONLINE BRAND EVANGELISM BEHAVIOUR
}

\author{
HASNIZAM SHAARI \\ INTAN SHAFINAZ AHMAD \\ School of Business Management \\ Universiti Utara Malaysia
}

\begin{abstract}
In line with social media development, the online brand community becomes an alternative media that could contribute to overall brand success or vice versa. Among others, the online brand community could significantly affect brand evangelism behaviors. This study attempts to extend the understanding on how members' brand community commitment influences brand evangelism which is considered as an extra-role behavior from the members. The study among 167 members of the online brand communities revealed that brand evangelism is explained by the unidimensional construct. The result indicates that trust towards the online brand community and brand community commitment significantly affect brand evangelism. Implication and future research direction are also highlighted at the end of this article.
\end{abstract}

Keywords: Marketing, brand community commitment, brand evangelism, social media

\section{Introduction}

Social media has changed todays' social communication landscape at large. We are now confronted with the 'referral powered' community. Consumers' attitude and behavior towards certain brands can be easily influenced by just a referral from someone they trust and respect. It is true in today's digital marketing environment, where almost every one of us belongs to specific brand communities. For instance, Kozinet (1999) forecasted that over 40 million people will belong to one or more online communities in the next millennium. More importantly, consumers' interaction through the social media or blogs cannot be controlled. Consumers' can express both their favorable and unfavorable feelings towards the brand via the online medium thus limiting the owner of the brand to control the flow of communication among the members. Thus, Cruz and Mendelsohn (2010) claimed that nowadays, customers and potential customers have more control of the overall brand performance (especially relates to image and reputation building) compared to the owner of the brand itself. Therefore an online brand community plays a crucial role in enhancing or diminishing overall marketing activities. Previous researches had also indicated that online brand communities play a crucial role in enhancing an organization's brand success such as loyalty, increasing market penetration, boosting revenue and creating positive word - of - mouth advertising (Hagel \& Armstrong, 1997; Kim, Choi, Qualls \& Han, 2008).

Despite the growing importance of the online brand community and/or the social media as new tools for integrated marketing communication, little focus has been given to understand the contribution of the online brand community and its commitment to overall brand success. The mixed results of previous studies highlighted the urgency of the study to broaden into new contexts and sample with additional antecedents and consequences (Casalo, Flavion \& Guinaliu, 2010a; Cheung, Lee \& Rabjohn, 2008; Kim, 
Choi, Qualls \& Han, 2008). Previous studies attempted to explore the consequences of online brand community based on different perspectives such as brand resonance (brand satisfaction and loyalty) (Hur, Ahn \& Kim, 2011) as well as brand evangelism (Becerra \& Badrinarayanan, 2013; Doss, 2013; Collins, Glabe, Mizerski \& Murphy, 2015). Doss conceptualized brand evangelism as a unidimensional construct, where as Becerra and Badrinarayanan (2013), outlined three major dimensions, namely intention to purchase, positive band referral and oppositional brand referral. The recent study of Collins Glabe, Mizerski and Murphy (2015) revealed that brand evangelists are higher in terms of satisfaction, perception towards value of the brand, purchase intention, cultishness and knowledge-orientation.

According to Cruz and Mendelsohn (2010), members of the brand community become more engaging and are more likely to buy and recommend the brand to others as compared to non-members. This is supported by the study of Becerra and Badrinarayanan (2013), which found that members who demonstrated high brand identification towards their brand community would contribute to brand evangelism (such as positive referral, oppositional brand referral and intention to purchase the brand). However, in reality, word-of-mouth or brand referral could be positive or negative. For instance, in 2014, McDonald Malaysia was terribly affected by the Islamist boycott due to negative allegations from the social media that claimed McDonalds' Malaysia supported Israel (Jain, 2014).

Commitment itself is not easily built especially in the context of the online community. Ba (2001) suggested that trust was a critical determinant for members to commit to the community that later influenced their behavior toward the brand such as brand evangelism. Trust is expected to be more important in the context of the online community as members may come from diverse backgrounds and not knowing each other. This is supported by Shaari and Ahmad (2015) that suggested brand trust among the online community members failed to influence the intention to purchase new products (i.e. a part of evangelism behavior). Hence, it is important to understand how customers especially members of the online brand community trust and commit to the brand community and how they contribute to strengthen the brand equity through their brand evangelism behavior. This study attempts to examine the possible brand evangelism behaviors among the online brand community especially in Malaysia and to examine the effect of brand trust and brand community commitment among the online community members on the brand evangelism behaviors.

\section{Literature Review}

Online community is defined as an aggregation of people who share a common interest and communicate through electronic mailing lists, chat rooms, Internet user groups or any other computer-mediated mechanism (Kim, Choi, Qualls \& Han, 2008). Stokburger-Sauer (2010), defined brand community as a group of users and admirers of the brand who engage jointly in group actions to accomplish collective goals and/or to express mutual sentiments and commitments. This is consistent with Muniz and O'Guinn (2001) who refer to brand community as ' $a$ specialized, non-geographical bound community, based on a structured set of social relationships among admirers of the brand' (p.412). Based on these definitions, this study defines online brand community as a social relationship among the users and the admirers of the brand to accomplish collective goals and/or to express mutual sentiments and commitments online.

Brand community commitment refers to the extent of the members psychological attachment to an online community and their belief in the value of the relationship (Kim, Choi, Qualls \& Han, 2008). Kim, Choi, Qualls and Han (2008) argued that concept of commitment is needed urgently to be employed in the online environment as customers become more Internet-dependent for information and purchases. Everything, including brand switching, could be done simply withone click. This, warrants organizations to have a deeper understanding on how commitment will affect consumers' brand evangelism especially in the online context. 
Previous studies explored how brand community commitment would contribute to brand satisfaction and loyalty (Gummerus, Liljander, Weman \& Pihlstroom, 2012; Laroche, Habibi, Richard \& Sankaranarayanan, 2012; Hung, 2014; Jang, Olfman, Ko \& Koh, 2008), but little had attempted to link how those committed members would elicit brand evangelism (Becerra \& Badrinarayanam, 2013). Brand evangelism was first coined by Kawasaki (1991), and is an extension of the word-of-mouth (WOM) conception (Doss, 2013). According to Kawasaki (1991) customer evangelism refers to customer who is intrinsically motivated to zealously spread WOM. Collins and Murphy (2009) defined evangelism as users of the brand or product who volunteer their time and resources recommending the use of that product or brand. The study by Becerra and Badrinarayanam (2013) among 325 members of the brand community indicated that the feeling of brand commitment would influence positive brand referral and oppositional brand referral. A study by Doss (2013) among 425 members of the Harley Davidson, MINI, iPhone and Saab brand community revealed that brand identification had a significant direct relationship to brand evangelism. However, brand evangelism was conceptualized as a unidimensional construct. Collins and Murphy (2015) proposed that brand evangelism could be conceptualized as multidimensional constructs. Hence, this study attempts to conceptualize brand evangelism based on multidimensional constructs. Based on the literature, this study conceptualized brand evangelism into two major constructs namely positive brand referral (providing positive referrals regarding the brand) and oppositional brand referral (the act of dissuading others from consuming competing brands). The selection of the dimensions was based on the work of Becerra and Badrinarayanam (2013). Moreover, selected dimensions were also observed to be a common consequences of brand community commitment which had been tested separately in previous researches. Thus, it is hypothesized that:

H1 : Brand community commitment has a significant relationship on brand evangelism
Brand trust refers to willingness of the average consumers to rely on the ability of the brand to perform its state function (Chaudhuri \& Holbrook, 2001). Brand trust received considerable attention in business-to-business context mainly to establish long-term marketing relationship, stable transactions and committed relationships (McDonald, 1981). According to Doney and Cannon (1997), trust involves the element of 'calculative process' whereby, people tends to commit to the relationship based on cost versus benefit evaluation. Fuller, Matzler and Hope (2008) added that brand trust is reflecting on how consumer believed that brand is delivering the brand promise accordingly. The higher the tendency the brand to keep it promise, the more customers will be loyal to the brand. In the context of this study, it is postulated that, the more the customers have trust toward the brand, the higher their brand commitment and the higher their tendencies to engage in evangelism behavior. Hence, it is hypothesized that:

\section{H2 : brand trust has a significant relationship on brand evangelism}

\section{Research Methodology}

This study was cross-sectional study and was based on a non-contrived setting. Selfadministered were had been distributed to the respondents through mall intercept. Six shopping malls in Kedah, Penang and Perak were selected for this study. These shopping malls were selected due to their major attraction for the local community. Respondents were randomly selected during their checkouts from the shopping mall. Every $10^{\text {th }}$ shopper was approached. Through screening procedures only respondents identified as members in any online brand community were selected (Hur, Ahn \& Kim, 2011). According to Green (1991) the rule of thumb, a sample size for examining relationships should be larger than 50. Green suggested that $\mathrm{N}>50+8 m$ (where $m$ is the number of IVs). This study consisted of two independent variables, thus the adequate sample size should be $66[50+8(2)]$. In considering a low response rate for the mall intercept survey 
(Homik \& Ellis, 1988), 300 questionnaires were distributed in six major shopping malls in Taiping, Kulim, Sungai Petani, Penang and Alor Setar. However, based on pre-data screening, only 167 responses were usable. Hence, the percentage usable was $55.7 \%$. The usable percentage rate was consided acceptable, it was consistent with Hornik and Ellis (1988) theresponse rate for mall intercept is lower than other survey methods. The remaining data could not be analyzed due to too many missing values and unanswered questions.

The questionnaire consisted of several, sections mainly to gain information regarding consumers' belief, attitude and behavior towards their online brand community. The first part detailed members' demographic profiles including gender, ethnicity, income and education attainment mainly in a dichotomous scale. The second part comprised the measurement for brand trust, brand community commitment and brand evangelism. The measure for online brand community commitment and brand trust were adapted from Hur, Ahn and Kim (2011) with 4 items and three items respectively. The brand evangelism measure was adopted from Becerra

\section{Table 1}

\section{Construct and Measurement Items}

\begin{tabular}{llccc}
\hline Construct & Item & Loadings & AVE & CR \\
\hline Brand commitment & BIV1 & 0.692308 & 0.641164 & 0.876577 \\
& BIV2 & 0.848912 & & \\
BIV3 & 0.845957 & & \\
Brand evangelism & BIV4 & 0.80565 & & \multirow{2}{*}{0.892876} \\
& BVI1 & 0.877915 & 0.736254 & \\
Brand trust & BVI2 & 0.914794 & & \\
& BVI3 & 0.775357 & & \\
& BII1 & 0.795117 & 0.679352 & \\
\hline
\end{tabular}

Convergent validity refers to the extent to which the items measuring the same concept are in and Badrinarayanan (2013) with 5 items. All measurements were on the 5-point Likert scale.

\section{Validation of Measure}

The validation of measurement was assessed through the measurement model while the hypotheses were tested using the structural model. The validation of measure included convergent validity, discriminant validity, and reliability that measured the goodness of the items and they were assessed before testing the hypotheses.

The reliability test was used to assess the interitem consistency of the measurement model. The reliability of all the constructs was observed through Composite Reliability. Two items of brand evangelism (i.e. both items for brand oppositional referral) were dropped due to low loading value. Hence, using this sample, it was concluded that, brand evangelism was best explained by the unidimensional construct namely, positive brand referral. Table 1 summarizes the result of all values above the acceptable value (0.6) (Bagozzi \& Yi, 1988) after deleting the two items. 
the measurement model (Coltman, Devinney, Midgley \& Venaik, 2008). It was evaluated using the Average Variance Extracted (AVE) as suggested by Fornell and Larcker (1981). Following Chin is (1998) recommendation, all latent constructs should be above 0.50 (see Table 2).

Discriminant validity refers to the degree to which items measure different concepts. Discriminant validity also follows the suggestion of Fornell and Larcker (1981). This was accomplished by comparing the squared correlation of the paired constructs with the AVEs of each construct. To achieve adequate discriminant validity, the square root of the AVE should be greater than the correlation among the latent constructs (Fornell \& Larcker, 1981). Based on Table 2, all the values of the square root of the AVE are greater than the value of the correlation of latent construct, thus suggesting adequate discriminant validity. Therefore, it was concluded that the measurement model was valid and reliable.

Table 2

Discriminant Validity

\begin{tabular}{lccc}
\hline & Brand commitment & Brand referral & Brand trust \\
\hline Brand commitment & $\mathbf{0 . 8 0 0 7 2 7}$ & & \\
Brand evangelism & 0.584986 & $\mathbf{0 . 8 5 8 0 5 2}$ & \\
Brand trust & 0.548148 & 0.486452 & $\mathbf{0 . 8 2 4 2 2 8}$ \\
\hline
\end{tabular}

\section{Findings and Discussion}

The respondents' profiles of this study are presented in Table 3 . Table 3 shows the majority of the respondents were female $(62.9 \%)$ and from generation $\mathrm{Y}$ (aged between 16 to 25 years old) $(59.3 \%)$. In terms of ethnicity, the majority of the respondents were Malays (72.5\%) followed by Chinese (19.8\%), Indians $(6 \%)$ and other ethnic groups from Sabah and Sarawak (1.8\%). Most of the respondents were degree holders $(37.7 \%)$ and diploma holders (33.5\%). More than half of the respondents were students $(55.7 \%)$, followed by private sector employees (34.1\%), government servants (6.6\%) and self-employed (3.6\%). The majority of the respondents earned less than RM1000 specifically the students, followed by RM1001 to RM2000 (38.3\%) and RM2001 to RM3000 $(16.2 \%)$. Another $10.8 \%$ of the respondents earned more than RM3000 monthly.

Table 3

Respondent's Profile

\begin{tabular}{|c|c|c|}
\hline Category & Frequency & Percentage \\
\hline \multicolumn{3}{|l|}{ Gender } \\
\hline Male & 62 & 37.1 \\
\hline Female & 105 & 62.9 \\
\hline \multicolumn{3}{|l|}{ Age } \\
\hline 16 to 25 years & 99 & 59.3 \\
\hline 26 to 35 years & 45 & 26.9 \\
\hline 36 to 45 years & 23 & 13.8 \\
\hline 46 to 55 years & - & - \\
\hline Above 55 years & - & - \\
\hline
\end{tabular}




\begin{tabular}{lrr}
\hline Category & Frequency & Percentage \\
\hline Ethnicity & & \\
Malay & 121 & 72.5 \\
Chinese & 33 & 19.3 \\
Indian & 10 & 6.0 \\
Other & 3 & 1.8 \\
\hline Academic attainment & & \\
\hline Certificate & 44 & 26.3 \\
Diploma & 56 & 33.5 \\
Degree & 63 & 37.7 \\
Post graduate & 3 & 1.8 \\
Other & 1 & .6 \\
\hline Occupation & & \\
\hline Government servant & 11 & 6.6 \\
Private worker & 57 & 34.1 \\
Self-employed & 6 & 3.6 \\
Student & 93 & - \\
Other & - & 34.7 \\
\hline Income & & 38.3 \\
Less than RM1000 & 58 & 16.2 \\
RM1001 to RM2000 & 64 & 5.4 \\
RM2001 to RM3000 & 27 & 2.4 \\
RM3001 to RM4000 & 9 & 3.0 \\
RM4001 to RM5000 & 4 & \\
Above RM5000 & 5 & \\
\hline
\end{tabular}

The data was analyzed using SmartPLS 2.0 and SPSS 22.0. the bootstrapping procedure was employed to examine the hypothesized relationships. The result is shown in Figure 1 and Table 4.

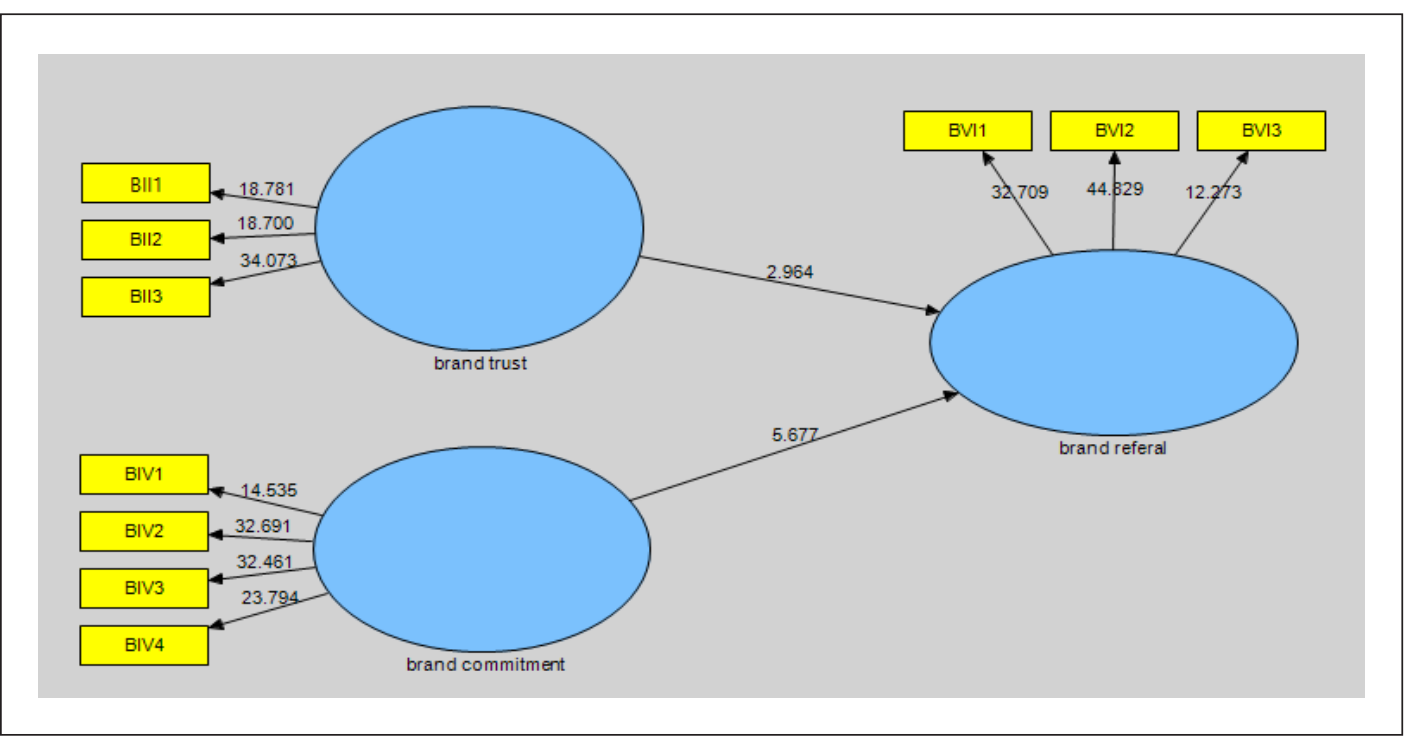

Figure 1. Structural Model

Hypothesis 1 predicted that brand community commitment is positively related to brand evangelism. Table 4 reveales that brand community commitment significantly affects 
brand evangelism $(\beta=0.455, \mathrm{t}=5.677, \mathrm{p}<0.01)$. Hypothesis 2 proposed that brand trust would significantly affect brand evangelism. Table 4 shows that brand trust significantly affects brand evangelism $(\beta=0.237, t=2.964, p<0.01)$. Hence, both $\mathrm{H} 1$ and $\mathrm{H} 2$ were supported. Overall, brand community commitment and brand trust explain $38.2 \%$ of the variance in brand evangelism.

Table 4

Structural Model Assessment

\begin{tabular}{llcccc}
\hline Hypothesis & \multicolumn{1}{c}{ Relationship } & Std. Beta & Std. Error & t-value & Decision \\
\hline H1 & $\begin{array}{l}\text { brand commitment }-> \\
\text { brand evangelism } \\
\text { brand trust }>\text { brand } \\
\text { evangelism }\end{array}$ & 0.455 & 0.080164 & $5.676762^{* * *}$ & Supported \\
H2 & 0.237 & 0.079951 & $2.964386^{* * *}$ & Supported \\
\hline
\end{tabular}

$* * \mathrm{p}<.01, * \mathrm{p}<.05$

Consistent with expectation, highly committed members among the online brand community will contribute to brand evangelism specifically on positive brand referral. Using this sample, members who have a favorable attitude towards brand community will recommend the brand to others, and have higher tendencies to leave positive comments on the communities' site. This result concurs with the findings of Hur et al. (2011). Becerra and Badrinarayanam (2013) also suggested that the higher the feeling of attachment (i.e. similar to brand commitment) among the members towards their brand community, the higher the tendency for them to engage in positive brand referral.

The results also suggest that brand trust (namely members' trust to brand community) would affect brand evangelism behavior, specifically positive brand referral. The online brand community is considered as a space for information sharing and exchange among the members. Anyone can post comments on the online community. As a result, members' trust of the community becomes crucial not only for providing positive comments but also commiting to constructive complaints (Hur, Ahn \& Kim, 2011). Although the strength of the relationship between brand trust and brand evangelism is relatively weak as compared to brand community commitment, trust to brand community will benefit all members (those who shared the information as well as those who will adopt the information). Ebrahimi (2011) noted that trust towards the community will determine members' adoption of information in online community context. Only if members trust their community, then only positive brand referral would be meaningful as it can easily be adopted by members.

This finding support Trust-Commitment Theory as suggest by Morgan and Hunt (1994). The two elements, namely trust and commitment, are found to be the best predictors to explain certain behavior. Based on the finding, these elements are even more important because online context is always subject to uncertainty and risk. Moreover, online brand community members normally are with diverse background and unknown to each another. Hence, members definitely will behave cautiously. Only highly committed members with adequate level of trust would become brand evangelist specifically towards engaging in positive brand referral. These members are the brand ambassadors and a key ingredient of future brand success.

As a marketer, social media development should be managed attentively. Online brand community that is based on social media platform could serve as strategic competitive advantage tools to be added to existing brand communication practices by an organization. 
Community is now becoming more sensitive and caring and lives in advance of information. Hence, marketers need to ensure the consistency of the brand message flows to the consumers mainly to establish long-term relationships. Inconsistent message even delivered by brand evangelist (especially online brand community) could tarnish the brand image and subsequently affect long term brand survival.

\section{Conclusion and Recommendation}

This study suggests both theoretical and managerial implications. It is observed that brand evangelism could be explained by unidimensional constructs. Members' participation and commitment in the brand community is not enough to make them engage in oppositional brand referral. This indicates that, even though members of the brand community have a strong community commitment, their referral is limited to providing a positive feedback of the brand and does not goes beyond comparing with the competing brand. This might hold true in the Malaysian culture to safe face by not condemning others. It is evident in the advertising practices in Malaysia where very seldom the audiences is exposed to direct comparative advertisement or messages from the competing brands. Based on the findings, it is proposed that practitioners need to address brand commitment and brand trust among the online communities effectively. Owners of the brand should seek the formula to strengthen the bond between the members and the brand as well as the community. Besides, managers also need to minimize the trust barrier in the online community context mainly to convert those 'calculus-based trust' members into transference-based trust' members.

The major limitation of this study is the size of the sample. The small sample size also limits the researcher to examine the effect of different brands on brand commitment, brand trust and brand evangelism. Future research should consider a huge sample that covers the whole nationwide sample and other brand community categories.

\section{Acknowledgements}

This study was conducted with a research grant funded by Universiti Utara Malaysia (S/O:13114).

\section{References}

Algesheimer, R., Dholakia, U.M., \& Herrmann, A. (2005). The Social influence of brand community:Evidence from European car clubs. Journal of Marketing, 69, 19-34.

Ba, S. (2001). Establishing online trust through a community responsibility system.

Decision Support Systems, 31, 323-336.

Bagozzi, R.P., \& Dholakia, U.M. (2006). Antecedents and purchase consequences of customer participation in small group brand communities. International Journal of Research in Marketing, 23, 45-61.

Bagozzi, R.P., \& Yi, Y. (1988). On the evaluation of structural equation models. Journal of the Academy of Marketing Science, 16(1), 74-94.

Becerra, E.P., \& Badrinarayanan, V. (2013). The influence of brand trust and brand identification on brand evangelism. Journal of Product \& Brand Management, 22(5/6), 371-383. DOI: 10.1108/JPBM09-2013-0394.

Casalo, L.V., Flavian, C., \& Guinaliu, M. (2010a). Determinants of the intention to participate in firm-hosted online travel communities and effects on consumer behavioral intentions. Tourism Management, 31,898-911.

(2010b). Relationship quality, community promotion and brand loyalty in virtual communities: Evidence from free software communities. International Journal of information Management, 30, 357-367.

Chatterjee, P. (2011). Drivers of new product recommending and referral behavior on social network sites. International Journal of Advertising: The Review of Marketing Communication, 30(1), 77101. DOI: 10.2501/IJA-30-1-077-101. 
Chaudhuri, A., \& Holbrook, M.B. (2001). The chain effects from brand trust and brand affect to brand performance: The role of brand loyalty. Journal of Marketing, 65(2), 81-93.

Cheung, C.M.K., Lee, M.K.O., \& Rabjohn, N. (2008).The impact of online opinions in online customer communities. Internet Research, 18(3), 229-247.

Collins, N., \& Murphy, J. (2009). Customer evangelism: A conceptual model. Retrieved from http://www.duplication. ne t . a u / A N Z M A C 09 / paper s / ANZMAC2009-301.pdf

Collins, N., Glabe, H., Mizerski, D., \& Murphy, J. (2015). Identifying customer evangelists. Review of Marketing Research, 12, 175-206. DOI: 10.1108/ S1548-643520150000012007.

Coltman, T., Devinney, T.M., Midgley, D.F., \& Venaik, S. (2008). Formative versus reflective measurement models: Two applications of formative measurement. Journal of Business Research, 61 (12), 1250-1262.

Cruz, B., \& Mendelsohn, J. (2010). Why social media matters to your business. Retrieved online from http://www.cmbinfo.com/ cmb-cms/wp-content/uploads/2010/04/ Why_Social_Media_Matters_2010.pdf

Doney, P.M., \& Cannon, J.P. (1997). An examination of the nature of trust in buyer-seller relationship. Journal of Marketing, 61(2), 35-51.

Doss, S. K. (2013). Spreading the good word: Toward an understanding of brand evangelism. Journal of Management and Marketing Research, 14, 1-15.

Ebrahimi, S. (2011). Information adoption in online communities: Elaborating the role of trust research. Retrieved online from http://aisel.aisnet.org/cgi/viewcontent.cg $\mathrm{i}$ ? article $=1242 \&$ context $=\mathrm{icis} 2014$

Fornell, C., \& Larcker, D.F. (1981). Evaluating structural equation models with unobservable variables and measurement error. Journal of Marketing Research, 39-50.
Fuller, J., Matzler, K., \& Hoppe, M. (2008). Brand community members as a source of innovation. Journal of Product Innovation Management, 25, 608-619.

George, D., \& Mallery, P. (2003). SPSS for Windows step by step: A simple guide and reference. 11.0 update (4th ed.). Boston: Allyn \& Bacon.

Green, S.B. (1981). How many subjects does it take to do a regression analysis? Multivariate Behavioral Research, 26, 499-510.

Gummerus, J., Liljander, V., Weman, E., \& Pihlstrom, M. (2012). Consumer engagement in a Facebook brand community. Management Research Review, 35(9), 857-877. DOI: 10.1108/01409171211256578.

Hagel, J., \& Armstrong, A.G. (1997). Net Gain: Expanding markets through virtual communities. Boston, M.A: Harvard Business School Press.

Hirschman, A.O. (1970). Exit voice loyalty. Retrieved online from http://www. thesocialcontract.com/pdf/four-four/ hirschma.pdf

Hornik, J., \& Ellis, S. (1988). Strategies to secure compliance for a mall intercept interview. Public Opinion Quarterly, 52, 539-551.

Hung, H. (2014). Attachment, identification, and loyalty: Examining mediating mechanisms across brand and brand community contexts. Journal of Brand Management, 21(7/8), 594-614. DOI: 10.1057/bm.2014.30.

Hur, W. M., Ahn, K.W., \& Kim, M. (2011). Building brand loyalty through managing brand community commitment. Management Decision, 49(7), 11941213.

Jain, A. (2014). McDonald's fights back Islamist boycott threat. Retrieved online from http://www.prweek.com/ article/1307071/mcdonalds-fights-backislamist-boycott-threat

Jang, H., Olfman, L., Ko, I., \& Koh, J. (2008). The influence of online brand community characteristics on community 
commitment and brand loyalty. International Journal of Electronic Commerce, 12(3), 57-80.

Kawasaki, G. (1991). Selling the dream. New York: HarperCollins.

Kim, J.W., Choi, J., Qualls, W., \& Han, K. (2008). It takes a marketplace community to raise brand commitment: The role of online communities. Journal of Marketing Management, 24(3-4), 409431.

Kozinets, R. (1999). E-tribalized marketing? The strategic implications of virtual communities of consumption. European Management Journal, 17(3), 252-264.

Krejcie, R. V., \& Morgan, D. W. (1970). Determining sample size for research activities. Educational and Psychological Measurement, 30, 607-610.

Laroche, M., Habibi, M.R., Richard, M.O., \& Sankaranarayanan, R. (2012). The effect of social media based brand communities on brand community markers, value creation practices, brand trust and brand loyalty. Computers in Human Behavior, 28, 1755-1767. DOI; 10.1016/j.chb.2012.04.016.

Mangold, W. G., \& Flauds, D. J. (2009). Social media: The new hybrid element of the promotion mix. Business Horizon, 52, 357-365.

Matzler, K., Pichler, E., Fuller, J., \& Mooradian, T. A. (2011). Personality, personbrand fit, and brand community: An investigation of individuals, brands, and brand communities. Journal of Marketing Management, 27(9/10), 874-890. DOI: 10.1080/0267267X.2010.543634.
McDonald, G.W. (1981). Structural exchange and marital interaction. Journal of Marriage and the Familiy, 43(4), 825839.

Morgan, R. M., \& Hunt, S.D. (1994).

The Commitment-Trust Theory of

Relationship Marketing. Journal of

Marketing. 58 (3), 20-38.

Muniz, A.M., \& O'Guinn, T.C. (2001).Brand community. Journal of Consumer Research, 27(4), 412-432.

Ramayah, T., Wai, C. L., \& Boey, C. I. (2011). Network collaboration and performance in the tourism sector. Serv Bus, 5, 411428.

Shaari, H., \& Ahmad, I.S. (2015). Does online brand community commitment influence intention to purchase new product: Initial study. Proceedings of $2^{\text {nd }}$ International Conference on Media and Society. Unimas, Kuching: Unimas.

Stokburger-Sauer, N. (2010). Brand community: Drivers and outcomes. Psychology \& Marketing, 27(4), 347-368.

Stokburger-Sauer, N., Ratneshwar, S., \& Sen, S. (2012). Drivers of consumer-brand identification. International Journal of Research in Marketing, 29, 406-418.

Zhang, N., Zhou, Z., Su, C., \& Zhou, N. (2013). How do different types of community commitment influence brand commitment? The mediation of brand attachment. Cyberpsychology, Behavior, and Social Networking, '6(11), 836-842. DOI: $10.1089 /$ cyber.2012.0456. 